\title{
GÊNERO, PODER E EDUCAÇÃO NO BRASIL DO SÉCULO XX
}

\section{GENDER, POWER AND EDUCATION IN BRAZIL OF THE $20^{\text {TH }}$ CENTURY}

\author{
Lucas Woltmann Figueiró*
}

\section{Introdução}

Há três anos tenho me dedicado ao estudo das relações entre gênero e o discurso do desenvolvimento. A origem da problemática aqui desenvolvida pode ser rastreada em meu interesse em investigar práticas de mediação social, política e cultural em projetos de desenvolvimento rural. Nesse percurso, o trabalho de campo realizado numa instituição de promoção do desenvolvimento no estado do Rio Grande do Sul me conduziu ao estudo crítico do campo de conhecimentos da economia doméstica e das representações sobre a mulher e sua "função social” para o desenvolvimento nacional entre a metade do século XX e o início do XXI. Mais recentemente, interessado em valorizar a memória literária da mulher brasileira e dar seguimento à minha curio- sidade científıca, passei a pesquisar periódicos (jornais, revistas, semanários, etc.) dirigidos e/ou redigidos por e para mulheres no Brasil do final do século XIX à metade do século XX. Isso se aguçou com o desenrolar da disputa presidencial no Brasil, no ano de 2018, quando a agenda "gênero" foi alçada ao topo da discussão pública. Buscando discutir a natureza política subjacente à produção da diferença de gênero, o presente artigo representa uma síntese das principais questões analisadas nessa trajetória.

A retórica direcionada às mulheres, à comunidade LGBTQI ${ }^{1}$, quilombolas, indígenas e ativistas de toda ordem, não foi uma novidade para quem acompanhava a atuação do até então Deputado Federal pelo estado do Rio de Janeiro, Jair Bolsonaro (Partido Social Liberal - PSL). No entanto, nos últimos anos e mais especialmente ao longo

\footnotetext{
* Doutorando em Antropologia Social na Universidade Federal do Rio Grande do Sul - UFRGS - (Porto Alegre/RS/BR). E-mail: lucas.woltmann@ufrgs.br

1. Sigla utilizada para referir a lésbicas, gays, bissexuais, travestis, transexuais, transgêneros, queer, intersexo e assexual.
} 
da corrida eleitoral pela presidência da República contra seu principal adversário, o ex-Ministro da Educação dos governos de Luiz Inácio Lula da Silva e Dilma Rousseff, Fernando Haddad (Partido dos Trabalhadores - PT), o que Jair Bolsonaro qualificou (e demonizou) como "ideologia de gênero" se tornou um dos pilares de sua atuação política. Impulsionados pela Frente Parlamentar Agropecuária (conhecida como "bancada ruralista”, pelo crescimento de uma pauta moral de ordem conservadora e da ascensão de grupos pentecostais e neopentecostais (representada no Congresso Nacional pela chamada "bancada da bíblia"), Bolsonaro e sua rede de apoiadores passaram a denunciar uma espécie de conspiração de "gênero": uma agenda subversiva dedicada a minar os valores familiares e religiosos e a promover a imoralidade.

Figuras como o próprio Jair Bolsonaro, o Deputado Federal Marco Feliciano (Partido Social Cristão - PSC), o à época senador Magno Malta (Partido da República PR) e outros representantes conhecidos do bloco parlamentar evangélico passaram a submeter, com certa regularidade, projetos de lei visando o reconhecimento de "direitos" aos fetos, definir a "família padrão" como uma unidade composta por um homem, uma mulher e suas/seus filhas/os, criminalizar o aborto (mesmo em caso decorrente de estupro) e outras pautas convergentes. Não por acaso, esse tipo de proposição vinha acompanhada de representações sobre a mulher alinhadas aos valores morais e religiosos de ordem conservadora que defendiam - tal qual a imagem "bela, recatada e do lar" apresentada, naquele momento, pela primeira-dama Marcela Temer à Revista Veja no ano de 2016. Mesmo que essas propostas não tenham sido aprovadas, permitiram que o bloco evangélico se apresentasse como defensor dos valores tradicionais da família e do cristianismo, provocando controvérsias públicas acaloradas. 0 argumento defendido era que os valores da família e da sociedade brasileira estariam "sob ataque", e, para salvá-los, uma guerra precisava ser travada contra a imoral e subversiva "ideologia de gênero".

Essa "cruzada anti gênero" também ganhou força pela divulgação de notícias falsas que associavam seus adversários à presidência, Fernando Haddad e a vice Manuela D’ávila (Partido Comunista do Brasil - PC do B), à promoção do que se convencionou (de forma equivocada) chamar de "kit gay". A alcunha pejorativa teve início no ano de 2004, quando o governo federal lançou o programa "Brasil sem Homofobia”, ação que tinha como objetivo combater a violência e o preconceito contra a população LGBTQI. Parte desse programa, a saber, enfatizava a relevância da formação de educadores para tratar questões relacionadas a gênero e a sexualidade, nascendo aí o projeto "Escola sem Homofobia”. Por meio de um convênio firmado pelo Fundo Nacional de Desenvolvimento da Educação (FNDE), foi elaborado um material para ser distribuído às instituições de todo país. No ano de 2011, pronto para ser impresso, setores da sociedade e do Congresso Nacional iniciaram uma campanha contra o projeto e o material elaborado. Dentre as críticas feitas, o material foi acusado de "estimular o homossexualismo e a promiscuidade”. Nessa disputa, a pressão das forças conservadoras prevaleceu e impediu sua circulação.

Desde sua idealização até o auge da disputa eleitoral em 2018, o impasse político cresceu. 0 tema se tornou fundamental nos argumentos de resgate dos valores familiares e cristãos que se articulavam com a retórica moralista e anticorrupção do, à época, 
candidato do PSL. De lá para cá, mesmo com a demonstração de força de movimentos feministas contra o candidato, vide a popular campanha “\#EleNão”, o presidente eleito Jair Bolsonaro afirmou em seu discurso da vitória que sua atuação dependia da Bíblia, "a caixa de ferramentas para consertar homens e mulheres", demonstrando que continuaria no mesmo rumo trilhado na campanha com a retórica anti gênero. 0 assunto tem surgido de forma acalorada no debate público sobre o projeto "Escola sem Partido", proposta que advoga por uma postura "neutra" - se é que isso é possivel do professor em sala de aula, não "interferindo" em certas opções políticas ou morais da formação do educando, o que incluiria discutir temas como gênero e sexualidade. Esse tipo de disputa revela o que está em jogo hoje: versões de homem, mulher, normalidade e desvio, formas de produzir diferenças e enfrentar (ou não) as muitas desigualdades e violências que geram.

Desde percursores de argumentos pós e descoloniais a intelectuais feministas se discute o fato de a produção da diferença ser relacional. Esse tipo de perspectiva epistemológica revela um movimento de recusa às reificações e essencialismos em favor da atenção a processos dinâmicos e instáveis de construção de instâncias e categorias. Frantz Fanon, por exemplo, já apontava em Peles Negras, Máscaras Brancas (2008 [1952]) que é do "outro", da relação, via gestos e atitudes em certas circunstâncias que emerge o "eu". Assim, o negro não existe, tampouco o branco, a diferença seria resultado da relação onde um "passa pelo crivo do outro" (FANON, 2008, p. 104). Na visão de Donna Jeanne Haraway (2003), os entes não preexistiriam à relação, ou mesmo existiriam de uma vez por todas: sujeitos, objetos, tipos, raças, gêneros e sexos seriam produtos de relacionamentos. Para ela, ao negar dualismos e universalismos, a teoria feminista abre caminho para pensarmos as emergências, os processos e a valorização da contingência. Numa linha semelhante, Amade M'Charek (2010) argumenta que a diferença não deveria ser entendida como algo objetivo ou dado, à espera de descoberta ou explicação, mas como efeito de um jogo complexo de relações entre pessoas, coisas e circunstâncias. Diferenças podem ser frágeis e efêmeras, esvaindo-se em questão de segundos, ou mesmo sendo duradouras, ganhando mais legitimidade através do tempo e das relações e estereótipos, de que é tributária, mas sempre estariam em transformação.

Isso significa que, no que tange à pesquisa e produção do conhecimento do que seria masculino ou feminino e seus derivados, não interessa uma definição última ou transcendental, e sim os processos e as circunstâncias históricas de sua construção, dos modos como as fronteiras ou as nuances entre ambos são produzidas e perpetuadas. Na esteira dessas premissas, o interesse geral que atravessa o presente artigo é estudar as representações sobre a mulher brasileira ao longo do século XX, não de forma exaustiva ou definitiva, mas através de exemplos que expressem o tom mais recorrente do que estava (e, como veremos, segue) em jogo nesse tipo de disputa. Para tal, me apoio em três fontes de pesquisa: o periódico Revista Feminina, publicado na cidade de São Paulo entre 1914 e 1936; o livro Noções de Economia Doméstica, publicado em 1958, com autoria de Isabel de Almeida Serrano, produção capaz de representar bem esse campo de conhecimentos, à época de seu lançamento; e os painéis do Encontro de Economia Doméstica de 1961, sediado na cidade do Rio de Janeiro com a finalidade de discutir o "papel" da mulher 
e desse campo de conhecimento na busca pelo desenvolvimento do país. 0 objetivo é explorar como significados e predicados que suscitam o feminino foram invocados para produzir diferenças e também prescrever ou contestar certas representações, em vez de outras, nesse período que as fontes citadas contemplam.

Para dar conta desse objetivo, articulo termos como discursos, representações, significados e gênero, reflexos de minha inspiração epistemológica na perspectiva pós-estruturalista desenvolvida por Michel Foucault e nas leituras promovidas por Edward W. Said, Stuart Hall e Joan W. Scott. Além desses/as autores/as, procuro não perder de vista intelectuais de diferentes origens disciplinares e inspirações teóricas cujo ponto em comum é a problematização do tema em questão, especialmente Guacira Lopes Louro, autora fundamental para o entendimento das relações entre gênero, poder e educação no Brasil - tópicos que nomeiam e justificam a existência do presente artigo. A ideia é demonstrar que, como pontua Michel Foucault (1997), as práticas discursivas não se referem puramente à fabricação de narrativas, já que ganham corpo (e, por consequência, produzem subjetividades) através de conjuntos técnicos, instituições, esquemas de comportamento, tipos de transmissão e difusão que, através de diferentes formas, as impõem e as mantêm ao longo do tempo.

No que tange à estrutura, este artigo se divide em quatro seções, incluindo esta Introdução. Na segunda seção, apresento os principais recursos teórico-metodológicos utilizados, e em especial, os caminhos relevantes para a análise discursiva e o conceito de "estereotipagem", ideia fundamental para seguir adiante o tipo de investimento proposto. Na terceira seção, apresento, de forma breve, as condições sociais e políticas da mulher brasileira entre o século XIX e XX, e dou exemplos de como operam as práticas representacionais de "estereotipagem”, para isso me valendo das três fontes de pesquisa anunciadas. Por sua densidade, essa seção é dividida em duas partes. Na primeira, trato da imprensa periódica do início do século XX, apresento a Revista Feminina e analiso cinco de suas edições publicadas em 1917, enquanto na segunda, exploro os predicados e as prescrições que se destacam nos painéis apresentados no Encontro de Economia Doméstica promovido em 1961 e no livro Noções de Economia Doméstica, de 1958, escrito por Isabel de Almeida Serrano. Atentando para o que estava em disputa, em ambas as partes analiso as estratégias utilizadas em favor da invariabilidade de determinado conjunto de representações tidas como mais verdadeiras ou incontornáveis que outras. Ao fim, numa quarta e última seção, proponho um breve balanço conclusivo das análises realizadas.

\section{Discursos, representações e gênero}

Três perguntas orientam os esforços da presente seção: 0 que são discursos? Como proceder em sua análise? Como sentidos, práticas representacionais e gênero entram em cena? No célebre $A$ arqueologia do saber (1987), Michel Foucault sugere que o discurso de uma área específica de conhecimento seria formado por um conjunto de enunciados (quer eles tenham sido falados ou escritos) em sua dispersão de ocorrências, algo capaz de colocar em relação objetos, temáticas, teorias e conceitos diversos. Caberia à análise do discurso descrever essas dispersões, esses elementos que "não se organizam como um edifício progressivamente dedutivo" (FOUCAULT, 1987, p. 43), o que pas- 
sa por identificar as condições a que esses elementos estão submetidos e explorar as regras comuns que regem a sua formação e dão força à sua existência, coexistência, manutenção, modificação e/ou desaparecimento. No momento em que se torna possível definir determinada regularidade (uma ordem, correlações, posições e funcionamentos específicos, transformações, etc.) em um determinado número de enunciados, estaríamos diante de uma formação discursiva.

Em sua perspectiva, Michel Foucault (1987) renuncia à ideia de uma irrupção do acontecimento verdadeiro, da crença de que "além de qualquer começo aparente há sempre uma origem secreta", algo que conduziria a análise a um "ponto indefinidamente recuado" e "jamais presente em qualquer história" para afirmar: "Não é preciso remeter o discurso à longínqua presença da origem; é preciso tratá-lo no jogo de sua instância" (FOUCAULT, 1987, p. 28). Para ele, a análise do campo discursivo precisa ser orientada para a compreensão do "enunciado na estreiteza e singularidade de sua situação", buscando determinar "as condições de sua existência, de fixar seus limites da forma mais justa, de estabelecer suas correlações" com "outros enunciados a que pode estar ligado, de mostrar que outras formas de enunciação exclui” (FOUCAULT, 1987, p. 31). Dessa forma, o que está em questão é o estudo dos sistemas de regras que possibilitam a ocorrência de certos enunciados em determinadas épocas, lugares e instituições, em detrimento de outros.

No entanto, ainda que os discursos precisem ser tratados em sua instância, é preciso levar em consideração que sempre pressupõem "algum conhecimento prévio, a que se refere e em que se baseia”, já que cada escrito se associa, direta ou indiretamente, a outras obras, públicos, instituições, “cuja pre- sença no tempo e no discurso lhe dá força e autoridade" (SAID, 2007a, p. 51). Edward W. Said compartilha com Michel Foucault a percepção de que os enunciados respondem a discursos anteriores e viabilizam outros. Enunciar, portanto, é situar-se em relação a um já dito e a uma possibilidade, ficando "ligado não apenas a situações que o provocam, e a consequências por ele ocasionadas, mas, ao mesmo tempo, e segundo uma modalidade inteiramente diferente, a enunciados que o precedem e o seguem" (FOUCAULT, 1987, p. 32). No entanto, os autores divergem quanto à importância atribuída a um texto individual ou autor específico. Edward W. Said dá destacada relevância aos autores, talvez por conduzir sua análise através de leituras "minuciosas cuja finalidade é revelar a dialética entre o texto individual ou o escritor e a complexa formação coletiva para a qual sua obra contribui” (SAID, 2007a, p. 54), ao passo que Michel Foucault (1997), ao contrário, parece argumentar que o conjunto de regularidades discursivas nunca coincidiria com obras individuais, mesmo que se manifestem através delas, ou que apareçam pela primeira vez justamente dentro de alguma delas.

Inspirado em Michel Foucault, Stuart Hall (2016) vê os discursos como formas de se reportar ou construir conhecimentos sobre um determinado tópico, um "termo geral" usado para fazer referência a qualquer abordagem em que o "sentido, a representação e a cultura são elementos considerados constitutivos" (HALL, 2016, p. 26). Na perspectiva desse autor, "o conceito de discurso" não seria "sobre se as coisas existem, mas sobre de onde vem o sentido das coisas" (p. 81). 0 conceito utilizado para palavras, sons ou imagens que carregam sentido é signo. Esses signos, por sua vez, indicam ou representam os conceitos e as relações entre 
eles que, articulados, constroem os sistemas de significado do que usualmente qualificamos como cultura (HALL, 2016, p. 37). Para Hall, todo o repertório pelo meio do qual a "diferença" é representada em certo momento histórico poderia ser descrito como um "regime de representação" (p. 150).

Todavia, se engana quem pensa que falar de significados não é tratar de poder ou política. Como Edward W. Said (2007b) sugere em Humanismo e crítica democrática, parte de sua atividade intelectual - incluindo o já clássico Orientalismo: o Oriente como invenção do Ocidente (2007a) - estava baseada na premissa da natureza imperfeita de todas as representações, de como elas estão intimamente atadas ao que o autor chama de "mundanidade", ou seja, ao poder, posições e interesses. Nesse sentido, como sugerem Stuart Hall (2016) e Joan W. Scott (2008), a perspectiva pós-estruturalista refuta a ideia do signo como sinal desvencilhado do contexto histórico, dando atenção, pelo contrário, à "natureza política" de sua construção. Nas palavras dessa intelectual:

[...] el estudio de los significados dirige nuestra atención hacia los complejos procesos que establecen los significados, hacia las formas en que tales conceptos, [...] adquieren la apariencia de alga fijo [...] en otras palabras, hacia las relaciones de fuerza involucradas en la construcción y aplicación de los significados de una sociedad: hacia la política. (SCOTT, 2008, p. 23)

Na interpretação de Stuart Hall (2016), objetos, pessoas, eventos e situações não possuiriam um significado fixo ou verdadeiro em si, mas o ganhariam a partir dos sentidos que lhe são atribuídos. Os significados, por resultado, sempre flutuam, e os sentidos, consequentemente, mudam de uma cultura ou período a outro (HALL, 2016). Sempre abertos à redefinição, os significados requerem um esforço de repetição e reafirmação por parte de quem os aprova (SCOTT, 2008), e quando aparecem inseridos em uma "tentativa de fixação", refletem o "trabalho de uma prática representacional que intervém nos vários significados potenciais" de "uma imagem e tenta privilegiar um deles" (HALL, 2016, p. 146). É nas disputas em torno de sua permanência ou superação que encontramos sua natureza política. Segundo este autor,

[...] o significado nunca pode ser fixado. Se isso pudesse ser feito por meio da representação, então não haveria qualquer mudança - e por isso, nenhuma constraestratégia ou intervenção. Nós, obviamente, fazemos grandes esforços para fixar o significado - é precisamente o que as estratégias de estereotipagem pretendem fazer, muitas vezes com considerável sucesso, por um tempo (HALL, 2016, p. 211).

Na análise de Stuart Hall (2016, p. 234), a "estereotipagem" operaria através de diferentes meios: essencialização, reducionismo e naturalização, ambos comumente associados a oposições binárias. Para ele, estereotipar significaria reduzir algo a certas características e justificar esse processo, em virtude de uma essência tomada como "natural". 0 processo de vincular homens e mulheres a certos atributos, funções, características, naturezas, é tão cotidiano quanto a própria existência e manutenção de versões de "masculinidade" e "feminilidade" desses conjuntos de representações que simbolizam e reduzem diferenças de forma mais ou menos esquemática. No entanto, o ponto em questão para esses/as intelectuais seria não embarcar nesse tipo de imagem de antemão, 
mantendo uma espécie de vigilância epistemológica: antes de aceitar qualquer tipo de classificação prévia ou marcadores da diferença como portadores de alguma "essência” à espera de ser revelada, seria preciso:

\section{[...] pôr em questão [...] essas sínteses acabadas, esses agrupamentos que, na maioria das vezes, são aceitos antes de qualquer exame, esses la- ços cuja validade é reconhecida desde o início; é preciso desalojar essas formas e essas forças obscuras [...]. (FOUCAULT, 1987, p. 24)}

Quando gênero é o tema em questão, isso passa por reconhecer que "homem" e "mulher" são, ao mesmo tempo, categorias vazias e transbordantes. Vazias pelo fato de não guardarem nenhum significado transcendente, e transbordantes porque, "mesmo quando parecem estar fixadas, ainda contêm dentro delas defınições alternativas, negadas ou suprimidas" (SCOTT, 1995, p. 93). Segundo Joan W. Scott, esse dilema pode ser enfrentado através do exame das "formas pelas quais as identidades generificadas são substantivamente construídas” e dos meios pelos quais se relacionam com toda "série de atividades, de organizações e representações sociais historicamente específicas” (p. 88). Segundo a autora, esse tipo de empreendimento passa por "descobrir o leque de papéis e de simbolismos sexuais" evocados em diferentes locais e períodos e "encontrar qual era o seu sentido e como eles funcionavam para manter a ordem social ou para mudá-la" (SCOTT, 1995 p. 72). 0 que está em jogo, enfim, é conceder

[...] atenção aos sistemas de significado, quer dizer, aos modos pelos quais as sociedades representam o gênero, servem-se dele para articular as regras de relações sociais ou para construir o significado da experiência.
Sem significado não há experiência; sem o processo de significação, não há significado. (SCOTT, 1995, p. 82)

Com esse tipo de orientação metodológica, a abordagem de Joan W. Scott nos conduz a pensar que nenhuma experiência corporal e subjetiva pode ser compreendida fora de processos sociais e históricos. "Gênero", dessa forma, surge como categoria de análise relacional e dinâmica. Em virtude da complexidade da questão, antes de seguir em busca do objetivo traçado, acredito ser pertinente tecer breves considerações sobre a historicidade e os dilemas do uso do conceito de "gênero" nas ciências sociais. Com todas as limitações que se possa considerar, estudos como As técnicas do corpo (1934) de Marcel Mauss, e Sexo e Temperamento (1936) de Margaret Mead, foram pioneiros ao sugerir que certos padrões de conduta não seriam reflexos imediatos da natureza dos homens e mulheres, mas sim de processos culturais e de socialização diversos. Na esteira desse tipo de percepção, a atuação crítica e criativa de intelectuais e militantes feministas, ao longo das décadas, abriu espaço para a consolidação de novas formas de produzir conhecimento e enfrentar as muitas desigualdades sociais e políticas em jogo. Nesse percurso, o conceito de "gênero" passou a ser usado para enfatizar o caráter cultural das desigualdades que assolam homens e mulheres, ao passo que a diferença "sexual" permanecia sendo entendida como algo natural e inscrito no corpo (MAZZARIELLO e FERREIRA, 2015).

Quanto a isso, Anne Fausto-Sterling (2001/02) sugere que a partir da década de 1970 cresceu a popularidade da ideia de que "sexo" e "gênero" seriam categorias separadas. "Sexo" expressaria atributos físicos que seriam anatômica e fisiologicamente deter- 
minados, enquanto "gênero" uma transformação psicológica do eu (espécie de convicção interior de que se é homem ou mulher) e as expressões comportamentais que dela decorreriam. 0 uso da expressão "identidade de gênero", por exemplo, seria tributário desse tipo de percepção. No entanto, em manifesta crítica a essa cisão, Anne Fausto-Sterling argumenta que, ao separar natureza (corpo, biologia) da cultura (social, história), o pensamento feminista acabou reduzindo o alcance de sua crítica ao não questionar o domínio do corpo no âmbito das discussões.

Segundo ela, Judith Butler foi uma das pioneiras a reivindicar a análise do corpo no pensamento feminista, sugerindo que, se existem hormônios, genes, útero e outras partes dos corpos utilizadas para diferenciar o "macho" da "fêmea", não deveríamos esquecer que as próprias variações nesses aspectos afetariam a experiência individual de gênero e sexualidade. Seguindo a análise que Fausto-Sterling faz de Judith Butler, pelas concepções ocidentais sobre matéria e materialidade corporal terem sido construídas com base em uma "matriz com gênero", já que "matéria” deriva de "mater [mãe] e matrix [matriz], referindo-se ao útero e a problemas de reprodução", tanto em grego como latim a matéria não poderia ser entendida como um "quadro vazio à espera da aplicação de sentido exterior”, pois já contém em si noções de gênero e sexualidade (FAUSTO-STERLING, 2001/02, p. 62). "Sexo" e "gênero", por conseguinte, já não parecem categorias tão estáveis. Mas se "gênero" foi formulado justamente para questionar uma resignação à biologia, e Fausto-Sterling e Butler (2003) estão nos propondo um olhar cauteloso sobre o par "sexo" e "gênero", parece que estamos diante de outro conjunto de problemas:
Podemos referir-nos a um "dado" sexo ou um "dado" gênero, sem primeiro investigar como são dados o sexo e/ou gênero e por que meios? E o que é afinal o "sexo"? É ele natural, anatômico, cromossômico ou hormonal, e como deve a crítica feminista avaliar os discursos científicos que alegam estabelecer tais "fatos" para nós? [...]. Seriam os fatos ostensivamente naturais do sexo produzidos discursivamente por vários discursos científicos a serviço de outros interesses políticos e sociais? Se o caráter imutável do sexo é contestável, talvez o próprio construto chamado "sexo" seja tão culturalmente construído quanto o gênero; a rigor, talvez o sexo sempre tenha sido o gênero, de tal forma que a distinção entre sexo e gênero se revela absolutamente nenhuma (BUTLER, 2003, p. 25).

Como resultado, parece arriscado definir "gênero" como interpretação cultural do "sexo", já que este também é fruto de um conjunto de discursos mediante o qual "a natureza sexuada" ou "um sexo natural” é produzido e entendido como "pré-discursivo, anterior à cultura, uma superfície politicamente neutra sobre a qual age a cultura" (BUTLER, 2003, p. 23). Esses dilemas nos conduzem para um terreno perigoso: sabendo que articular o sentido de uma palavra em um contexto onde há ambiguidade não é um ato meramente descritivo, mas político (NICHOLSON, 2000), como lidar com a noção de "gênero"? Consciente de suas limitações, mas reconhecendo seu poder analítico, o uso que faço do conceito de "gênero" no presente artigo não se refere a um predicado ou convicção interior de que se é ou não homem ou mulher, mas sim um "instrumento de comparação", recurso para entender o "modo" como as diferenças "entram em nossos cálculos” (STRATHERN, 1995, p. 304). Nesse 
sentido, valendo-me de recursos interpretativos oferecidos pela perspectiva pós-estruturalista, "gênero" é entendido como ponto relativo de convergência entre conjuntos de enunciados, relações e ações performativas, culturais e historicamente situadas, que agem a fim de produzir e reproduzir os significados que dão sentido às diferenças (BUTLER, 2003). Na próxima seção, apresento e discuto os modos pelos quais essa diferença é produzida e que práticas representacionais as sustentam e dão força visando sua manutenção ao longo do tempo.

\section{Produzindo diferenças, defendendo per- manências}

Não tenho pretensões de apresentar de forma detalhada ou exaustiva a condição social e política da mulher brasileira ao longo dos séculos XIX e XX, no entanto, algumas considerações pontuais podem nos ajudar a contextualizar o cenário mais amplo das desigualdades e disputas tratadas neste artigo.

Se nas primeiras décadas do século XIX o processo de escolarização da população brasileira ainda era incipiente e precário, o direito básico de aprender a ler e a escrever era reservado exclusivamente a (alguns) homens. A despeito de toda resistência, quando a presença de meninas passou a ser aceita nas escolas públicas na segunda década do século, somavam menos de 10\% do total dos matriculados, ao passo que no final do século sua proporção alcançava a casa dos 30\% (JINZENJI, 2012). Durante esse período, lutas e exemplos de inspiração se acumularam. No ano de 1887, por exemplo, a primeira mulher se tornava símbolo de mudança ao concluir sua formação superior em Medicina (NASCIMENTO e OLIVEIRA, 2007). No entanto, como sugere a histo- riadora Constância L. Duarte (2003), em meados do século XX a proporção de mulheres cursando ensino superior no Brasil ainda era muito pequena se comparada aos homens. No ano de 1929 havia, em todo o pais, 5.789 homens e 72 mulheres matriculados em cursos de Medicina, das quais apenas quatro concluíram a formação. Essa proporção era muito semelhante em outros cursos, como Odontologia, Filosofia, Letras, Ciências Jurídicas e Sociais, Engenharia Civil, Arquitetura, Agronomia e Veterinária.

Ao mesmo tempo que se discutia o direito e o acesso da mulher à educação, as lutas visando sua inserção política, social e produtiva na sociedade brasileira também ganhavam relevo. 0 início do século XX ficou marcado por intensas movimentações de mulheres mais ou menos organizadas, que reivindicavam o direito ao voto e à ampliação das oportunidades e campos de trabalho. Ao passo que clamavam por maior participação no âmbito público e em espaços decisórios, já não se resignavam ao posto de professoras ou à ocupação doméstica e ofícios relacionados, como costureiras, cozinheiras, etc., demandando formação e oportunidades no comércio, em hospitais, indústrias, entre outros. Os avanços foram graduais e significativos em ambos os campos. Quanto ao voto, mesmo que o ex-presidente Getúlio Vargas tenha cedido e reconhecido esse direito à mulher no Código Eleitoral de 1932, ele só seria concretizado de forma efetiva na disputa eleitoral de 1945 (DUARTE, 2003). No que tange à sua inserção social e produtiva, veremos na presente seção que, a despeito das conquistas e da ampliação das possibilidades, a educação e qualquer atividade profissional das mulheres no Estado Novo eram pensadas como reflexo direto de um conjunto de predicados e prescrições que associavam a mulher brasi- 
leira a ofícios ligados à esfera "reprodutiva".

Mas que representações serviam à manutenção ou à superação desse tipo de diferenciação e desigualdade? Visando problematizar esse tipo de questão, a presente seção possui dois propósitos diretamente inter-relacionados. 0 primeiro é explorar significados e predicados articulados para produção de certa imagem de feminino e, sobretudo, a preocupação que a promoção de ideais emancipatórios para mulher despertava em interessados/as na conservação de valores e costumes cristãos e familiares no Brasil. Isso é obtido através da análise de edições da Revista Feminina, exemplo interessante da (à época emergente) "imprensa feminina" dentro da indústria periódica brasileira. 0 segundo, por sua vez, é analisar a principal ferramenta para frear esses ideais: uma educação justificada por representações que, não por acaso, concebiam e sustentavam uma ligação "natural" entre a mulher e o bem-estar da familia e da sociedade. Para tal, exploro as apresentações de educadoras/es e agentes promotores do desenvolvimento na cidade do Rio de Janeiro em 1961, na ocasião do Encontro de Economia Doméstica, e percepções de Isabel de Almeida Serrano no livro Noções de Economia Doméstica (1958). Visando melhor apresentar minha argumentação, a presente seção está dividida em duas partes, cada qual referente a um propósito.

\subsection{Feminino em revista? 0 medo do amanhã}

De acordo com as historiadoras Constância L. Duarte (2016) e Karoline Carula (2016), antes de ser viável mulheres serem protagonistas da indústria periódica no Brasil, alguns homens da imprensa ofereciam jornais às leitoras. Até a segunda metade do século XIX, sugere Carula (2016, p. 262), as publicações periódicas destinadas à mulher eram escritas "essencialmente por homens", quando, então, passam a surgir "alguns jornais escritos por mulheres". A emergência de periódicos dirigidos e/ou redigidos por e para mulheres no Brasil deu origem ao que Mônica Y. Jinzenji (2012, p. 391) chamou de "Imprensa feminina", valendo o destaque para o Jornal das Senhoras (RJ), que circulou de 1852 a 1855 e é considerado o pioneiro. Segundo Duarte (2016, p. 22), esse jornal tinha como missão "propagar a ilustração" e cooperar "para o melhoramento social e a emancipação moral da mulher". A relevância do tratamento e análise desse tipo de material parece se justificar, tanto pela relevância de valorizar a memória literária das mulheres no Brasil, quanto pelo fato de representarem "plataformas de fixação de ideias e, por conseguinte, suportes incontornáveis para a história das mentalidades e dinâmicas sociais" (SALVADOR, 2009, p. 95).

Mesmo que a emergência desse tipo de periódico represente um ato de "afirmação da identidade pública das mulheres", valendo-me da interpretação da historiadora portuguesa Tereza Salvador (2009, p. 103), não devemos partir de nenhum a priori. Tendo como público-alvo as mulheres, cujo acesso à educação e à condição econômica lhes permitiam o privilégio da leitura, os periódicos publicados nesse período eram constituídos por temas e perspectivas diversas que, não raramente, alternavam propostas antagônicas. Seus conteúdos incluíam tanto textos e trechos literários, artigos sobre moda, decoração, culinária, defesa e propagação de valores e juizos morais sobre família, quanto escritos que reivindicavam mais direitos e igualdade. Ou seja, ora eram "canal de expressão para as sufocadas vocações literárias das mulheres" (MUZART, 2003, p. 228) e voz crítica da posi- 
ção social e política que ocupavam à época, servindo como plataforma para reivindicação pelo direito à educação, à profissão e ao voto; ora davam espaço para a defesa/ manutenção de valores e imagens do "feminino" associados à delicadeza e docilidade, sendo ressaltados os vínculos "naturais" da mulher com o lar e a missão (incontornável) da maternidade.

Na interpretação de Constância L. Duarte (2016), os periódicos refletiam a "dicotomia vigente" no período. De um lado, clamavam respeito e defendiam os direitos das mulheres; de outro, reiteravam imagens estereotipadas, limitando-se a tratar temas ligados à moda, ao doméstico e à maternidade. Essa ambiguidade conduz a autora a concluir que o processo de "emancipação intelectual, política e social da brasileira" ficava "à mercê de forças que ora a impulsionavam para a frente, ora a queriam estacionada na ignorância e na dependência” (DUARTE, 2016, p. 25). Para o que convém aos interesses deste artigo, a indústria periódica voltada à mulher brasileira como fonte de pesquisa representa a possibilidade de se debruçar sobre a "face visível de um vasto universo de papel construído para a leitora" desses "tempos, que a informava sobre as transformações históricas e sociais em processo" (DUARTE, 2016, p. 27). Mas que tipo de mudanças informavam? Ou melhor, que transformações defendiam ou faziam objeção?

Apesar da grande variabilidade em termos de designação desse tipo de escrito, transitando entre jornal, revista, semanário, periódico, ou mesmo na falta de referência à categoria, são muitos os exemplares disponíveis para consulta pública no Brasil hoje. 0 material que utilizo para análise foi obtido no sítio virtual da Biblioteca Nacional Digital, parte da Fundação Biblioteca Nacional. Dentre alguns dos periódicos publicados entre o final do século XIX e a metade do XX, pode-se citar o Echo das $D a$ mas (RJ), A Estação (RJ), A família (RJ/SP), Álbum das meninas (SP), O Momento Feminino (RJ), entre outros. Um periódico e um artigo em especial parecem mais representativos para o objetivo deste artigo: a $R e$ vista Feminina (SP) e o artigo "Vossas filhas sabem ler?”, escrito em $1916^{2}$ por Berenice Vieira, de Curitiba, e publicado em 1917 na edição número 32.

Inicialmente com o nome de A Luta Moderna, a Revista Feminina foi fundada no ano de 1914 por Virgilina de Souza Salles, diretora-proprietária até 1918. Filha de Antônia Barbosa de Souza e Cláudio Justiniano de Souza, membros da elite tradicional de São Paulo, Virgilina articulou seu periódico à Empreza Feminina Brasileira, empreendimento familiar do ramo que contava com a influência e o patrocínio de seu irmão Cláudio de Souza, escritor, teatrólogo e membro da Academia Brasileira de Letras (MANCILHA, 2011). Com o falecimento de Virgilina em 1918, a direção da empresa foi assumida por seu marido, o industrial João Salles, e suas filhas, Avelina e Marina Souza Salles, que também passaram a integrar o corpo editorial da Revista. Contando com escritos de colaboradoras/es e leitoras/

2. Esse ano marca o início de um período (que se estende até 1962) onde a legislação brasileira vigente sustentava a submissão da mulher. No Capítulo 1 do "Código civil dos Estados Unidos do Brasil”, "Das pessoas naturaes", via-se como incapazes de exercer "relativamente a certos atos [...], ou à maneira de os exercer", dentre outros, as "mulheres casadas, enquanto subsistir a sociedade conjugal" (BRASIL, 1916). Somente a partir da redação proposta pela Lei n 4.121, de 1962, conhecido como "Estatuto civil da mulher casada" (PINHEIRO, 2016), isso foi questionado. 
es, esse periódico foi publicado em São Paulo entre os anos 1914 e 1936 com a missão de buscar a emancipação das mulheres no interior da cultura católica tradicional, colocando em pauta temas que, à época, diziam respeito ao "universo feminino" (BONILHA, 2013).

Valendo-se de recursos gráficos inovadores para a época (fotografias, desenhos, etc.), as edições da Revista Feminina eram compostas por anúncios comerciais (de companhias de seguro, alimentos, oficinas de costura, roupas, produtos de higiene e remédios, móveis e artigos de decoração), contos (adultos e infantis), poesias, rezas e narrativas cristãs, seções e colunas opinativas sobre assuntos como moda, trabalhos artesanais e decoração, hábitos alimentares e sugestões de receitas, cuidado e saúde infantil, bem como, pautas em defesa do direito das mulheres ao voto, de suas capacidades intelectuais e do acesso à literatura e à arte. Como demonstro nas passagens citadas $^{3}$ a seguir, essa revista parece exemplificar muito bem o caráter ambíguo desse tipo de periódico na virada do século XIX para o XX, alternando entre anseios de "despertar todas aquelas energias anestesiadas pelo orgulho masculino e por preconceitos ridículos” (REVISTA FEMININA, 1917c, p. 14), e uma postura conservadora alinhada à "moral católica" que dava "tom à revista" (MANCILHA, 2011, p. 9).

Algumas passagens ajudam a exemplificar sua faceta mais transgressora. De forma jocosa e afiada, a ilustração "0 lar de uma suffragette”, publicada na edição 42 da Revista Feminina (1917e) propõe uma narrativa do dia a dia de um casal que inverte e subverte boa parte das imagens e expecta- tivas para os costumes, preocupações e atividades profissionais prescritas à época para homens e mulheres. Nela, o homem usa roupas de renda, um sapato com salto e fitas no cabelo, enquanto a mulher veste um fraque. Quando desfrutam a refeição do café da manhã, é "ele a servir enquanto ela lê $o$ artigo político. Ela vai em seguida para o escritório. Ele dá-lhe um beijo de despedida. E, ficando só em casa, vai lavar a roupa da família, enquanto sua mulher, médica, advogada, engenheira, etc., estará no escritório" (REVISTA FEMININA, 1917e, p. 24). A esse tipo de crítica se somavam reivindicações explícitas pelo direito ao voto, como sugere uma passagem da edição 39:

Nada mais irracional do que permitir à mulher o direito de ser educadora e negar-lhe o de ser eleitora. Um homem analfabeto não pode votar. A mulher, em escolas públicas, ofıciais, dá-lhe a instrução precisa e ele adquire imediatamente o direito de voto. No entanto, a professora, muito mais instruída que ele, continua a ser tida como incapaz! É um absurdo. (REVISTA FEMININA, 1917d, p. 41)

Em outras edições, as reivindicações se voltam para a defesa da capacidade intelectual da mulher e sua formação artística e científica. Na edição 35 do periódico, por exemplo, são feitas críticas aos "espíritos fúteis ou grosseiros" que consideravam a mulher brasileira "como incapaz de qualquer iniciativa no campo das ciências e das letras, apta apenas para os deveres domésticos e da maternidade" (REVISTA FEMININA, 1917c, p. 14). Entretanto, a despeito da força dessas passagens, era comum que esse tipo de posição viesse acompanhada de

3. De forma a facilitar o entendimento da/o leitora/o, as passagens citadas foram adequadas aos padrões gramáticas vigentes nos dias de hoje. 
imagens da mulher como portadora de uma natureza sensível/delicada e instável/nervosa. No artigo "Apelo às senhoras brasileiras”, assinado por Virgilina de Souza Salles, isso aparece de forma sútil e articulada a um tom otimista sobre os progressos culturais da mulher na sociedade nas primeiras décadas do século XX: "o espírito feminino brasileiro não é hoje o mesmo de [...] vinte anos, em que sua cultura se limitava a um curso de escola primária muito rudimentar", e mesmo "tendo-se conservado dentro de sua natural fraqueza" de "espírito", a mulher "evoluiu, leu, estudou e necessita hoje, de meios de expansão e de intercâmbio intelectual” (REVISTA FEMININA, 1917e, p. 12).

Por outro lado, o apelo às naturalizações e o tom conservador e moralizante da revista aparece com mais clareza em outros momentos. Algumas passagens da edição 42, por exemplo, naturalizam a mulher como sinônimo de vida, amor, sabedoria e bondade: "culminação da vida e a sublimidade do amor”, e quando "abre a boca é com sabedoria e as suas palavras são a lei da bondade" (REVISTA FEMININA, 1917e, p. 29). Em outras, tomando, por exemplo, a edição 34, as preocupações com a manutenção de sua moral ganham forma ao se transformar em dicas sobre condutas tidas como mais adequadas, o que inclui sugestões de como se portar ao receber um "cavalheiro das suas relações” em casa: a mulher deveria se valer de "todos os meios para não se comprometer, como deixando aberta a porta da sala e indicando para ele sentar-se um lugar em frente dela, afastado e nunca a seu lado" (REVISTA FEMININA, 1917b, p. 27).

Acentuando o caráter ambíguo desses periódicos, certas passagens clamam por igualdade entre homens e mulheres, ao mesmo tempo que reiteram a naturalização de diferenças de "vocações", “funções" e "qualidades" tomadas como inerentes a ambos. Na edição 42, consta que, "apesar de serem companheiros e iguais”, a potência de suas "faculdades" ou "vocações" seria, "claramente, definidos pela natureza", pois "Deus criou a mulher e o homem para que cada um execute" o "trabalho que lhe é destinado, na sua própria esfera”. Suas funções deveriam fazer jus a predicados inscritos em estereótipos que associavam o homem ao vigor e ao intelecto, e a mulher à fragilidade e ao afeto: "O homem tem mais força muscular e a fibra mais dura; a mulher é mais delicada, mais sensível, mais nervosa”. As qualidades do primeiro "pertencem mais ao domínio do cérebro e as da mulher ao coração", mas ainda que "a cabeça governe é o coração que influi”. A isso se somavam expectativas de manutenção da ordem social até então vigente: como ambos já estariam "igualmente adaptados às respectivas funções que têm a cumprir na vida”, tentar "impor ao homem o trabalho da mulher seria tão absurdo como querer impor à mulher o trabalho do homem" (REVISTA FEMININA, 1917e, p. 29).

Além desse tipo de questão, o caráter incontornável da missão feminina como esteio da família e da sociedade parece um dos tópicos mais recorrentes na revista. Isso surge, por exemplo, no artigo "Duas palavras” (REVISTA FEMININA, 1917e, p. 29), escrito por J. T. da Silva Braga e publicado na edição 42. Com objetivo de falar sobre a "emancipação da mulher", podemos ver como são tecidos os vínculos entre a atuação da mulher como mãe/esposa e o bem-estar da sociedade. Nesse escrito, são apresentadas as "teses" defendidas à época pelos "conservadores, para os quais o triunfo da mulher" trazia "como consequência a perversão dos costumes, o desmoronamen- 
to da sociedade". Em discordância, Silva Braga sugere que, a despeito dos temores, "em todos os países os costumes, as maneiras e o caráter do povo dependem” da mulher, ao passo que apenas "quando é depravada, a sociedade é depravada; quanto mais é pura e moralmente ilustrada, mais pura e ilustrada será a sociedade" (REVISTA FEMININA, 1917e, p. 29). Nesse mesmo artigo, é possível ver como a importância de progressos científicos e culturais da mulher era minimizada ante a missão "natural" de zelar pela família. Para Silva Braga, ao cumprir as tarefas domésticas e servir à preparação moral e física dos filhos, as mulheres "executam uma obra mais meritória do que se pintassem magníficos quadros, escrevessem lindos livros e compusessem grandes óperas”. Portanto, se as mulheres não escreveram obras de arte memoráveis, "não inventaram a álgebra, nem os telescópios, nem a máquina a vapor", sugere Silva Braga, elas estariam fazendo "coisas maiores e mais belas que tudo isso porque criaram sobre os seus joelhos seres retos e virtuosos, mulheres e homens, e essas são as mais belas produções do mundo" (REVISTA FEMININA, 1917e, p. 29).

Alinhado a esse tipo de narrativa, também eram comuns opiniões críticas às crescentes insatisfações de mulheres com obrigações familiares e domésticas. A edição 34 da revista sugere que, por vezes, a "frivolidade psicológica" da mulher "choca-se com esta situação como que de prisão forçada”, sentimento importante de ser combatido sob risco de gerar a "dissociação da família": "Não vamos buscar longe o que temos perto, ao nosso alcance. Sejamos felizes com aqueles para cuja alegria devemos contribuir e ponhamos toda a ternura nas nossas relações de família, de maneira que as nossas obrigações para com todos resul- tem doces, aligeirando-lhes e perfumandolhes a vida" (REVISTA FEMININA, 1917b, p. 34). Preocupados/as com o afastamento da mulher do âmbito doméstico, uma passagem da Edição 34, citada a seguir, nos conecta com o tema da educação, da leitura, do contato com novas ideias e do temor que isso causava em quem desejava manter os padrões e a ordem social hegemônica me valendo do sentido que Edward W. Said (2017a, p. 34) emprega ao termo usado por Antonio Gramsci, isto é, períodos históricos em que algumas das ideias se mostram mais influentes que outras, numa espécie de "liderança cultural":

Dentre todos os problemas [...] não há mais delicado que o das leituras. Como se há de determinar quais se devam permitir às donzelas? Quais de todo interdizer? Já não falando do mau livro, que hoje em dia por toda parte e sob todas as formas circula, deste livro malsão que pela base destrói toda a moral, toda a religião, alardeando o vício que se cobre de cores fascinantes e apresentam a virtude pálida, ridícula, ou as mais das vezes vencida, que há se deva proibir, autorizar? [...] Impede às donzelas de devorar os livros, a não ser que sejam tais que lhes dê lição de moderação; pois que uma leitura assim não acarreta nenhum proveito, antes serve para dar pábulo a uma curiosidade que se pode tornar perigosa. Ler demais é uma doença do século. (REVISTA FEMININA, 1917b, p. 18)

"Ler demais é uma doença do século". Esse tipo de questão nos conduz ao artigo "Vossas filhas sabem ler?", escrito por Berenice Vieira e publicado na edição 32 da $R e-$ vista Feminista (1917a). Esse artigo é emblemático para o objetivo do presente artigo, por ser capaz de ilustrar alguns dos argumentos que forjam esse sentimento de re- 
ceio de que os valores da mulher e da sociedade estariam em risco. Nesse escrito, Berenice Vieira narra um diálogo entre ela e um senhor não nomeado. Tudo começa com os lamentos desse senhor quanto ao fato de as mulheres arruinarem o mundo com "suas ideias de luxo", pois levariam os homens "muitas vezes até ao crime para satisfazer aos caprichos da mulher amada”. A resposta da autora desse artigo, entretanto, indica que "não são as mulheres que estragam o mundo: são os publicistas que estragam as mulheres, intoxicando-as com a fantasia inacessivel dos romances e com o estímulo das reportagens mundanas sensacionais”. Na percepção de Berenice Vieira, a maioria das mulheres continuava "a realizar seus sonhos dentro da paz e da sombra do lar, que tanto convém ao desabrochar de sua fragilidade”, no entanto, pelo contexto de transformações à época, essa tradição estava em xeque (REVISTA FEMININA, 1917a, p. 26).

Com a intenção de fornecer um exemplo "eloquente de síntese do momento atual entre homens e mulheres", ela narra um diálogo entre sua vizinha e o filho. Ao constituir o cenário desse diálogo, Berenice Vieira conta como o filho dessa vizinha, "enrodilhado pelo turbilhão do impulso que caracteriza nosso século", repetidamente retornava tarde para casa com o "cérebro perturbado pela política e pelo álcool dos cafés" que frequentava. Segundo ela, constantemente ele tentava "seduzir" sua mãe para conhecer as "teorias radicais com que o saturam os publicistas", que, no entanto, "tranquilamente" continuava a "cuidar de sua casa, de sua cozinha, de suas roupas, indiferente ao tumulto das ideias novas". Certo dia, voltando para casa já pela manhã, o filho foi ao encontro da mãe no estábulo. Enquanto sua mãe ordenhava uma vaca, ele a questionava sobre suas preferências polí- ticas, curioso para saber a posição de sua mãe entre os regimes presidencialista e parlamentarista. Após insistir para que ela respondesse, ouviu: "Sou apenas uma mulher que está tirando leite para dar ao filho que volta à casa a essas horas" (REVISTA FEMININA, 1917a, p. 26).

Segundo Berenice Vieira, seria assim que, de forma recorrente, as mulheres se veriam: "curvadas sobre o trabalho, dispondo o bem-estar de nosso lar, enquanto uma raça de pensadores ociosos e turbulentos, procuram seduzir-nos com teorias políticas e libertárias". Seguindo essa linha, ela reforça: "Não são as mulheres que arruínam o mundo, são os publicistas que arruínam as mulheres e o lar", já que "são eles que criam as mulheres que rejeitam os livros de cozinha e os jornais de costura, que sonham com a vida brilhante e que não querem ter filhos”. Essa narrativa, por fim, articula uma moral específica: "Deveis pois, mães de família, muito pesar o que dais a ler às vossas filhas, pois na brochura elegante, na ilustração pomposa, no panfleto de passo leve, pode ir escondida a traça daninha, que imperceptivelmente irá roendo os corações e os cérebros de vosso lar... Tendes na Revista Feminina a verdadeira leitura do lar" (REVISTA FEMININA, 1917a, p. 26).

Desse escrito, é possível ressaltar tanto a defesa de uma versão específica de feminino, que parece remeter à fragilidade, à maternidade, às tarefas domésticas e às predileções pela saúde e o bem-estar da família, quanto a afırmação da importância da atuação das mães em intervir nas leituras e na formação intelectual e moral das filhas, com vistas à promoção e a manutenção desse modelo de feminilidade ao longo das gerações. Além disso, esse artigo ilustra como através de narrativas do cotidiano são performadas estratégias que, cada qual à sua 
forma, intervêm a favor da estabilidade estereotipada e da invariabilidade de determinado conjunto de representações (BAHRI, 2013; HALL, 2016), ou seja, na manutenção de alguns significados em particular, que, não por acaso, excluem e atuam na contramão de outros possíveis. Não obstante o interessante relato em termos de caracterização, expectativas e prescrições sobre uma versão de mulher ideal, o artigo também é simbólico do peso (ou ao menos do temor) que a leitura de periódicos semelhantes, livros, práticas educativas e novos ideias veiculados à época poderiam gerar nas leitoras e na sociedade. Não por acaso, a educação e formação da mulher brasileira das décadas subsequentes acabou seguindo rumos que convergiam para a manutenção desse tipo de significados e representações, como veremos na próxima seção.

\subsection{0 papel regenerador: garantindo 0 amanhã}

Na análise de Mônica Y. Jinzenji (2012, p. 370-372), tanto as dimensões materiais quanto a legitimação sociocultural da escola como instância de ensino e aprendizagem se encontravam em sua fase germinal no Brasil das primeiras décadas do século XIX. As meninas, em especial, eram privadas de acessar as escolas públicas até o ano de 1814 , e mesmo quando sua presença passou a ser registrada, precisaram enfrentar resistências que iam desde "questões de natureza moral” à "importância como força de trabalho para a manutenção familiar". Entretanto, além desses limites e da desproporção entre meninos e meninas em termos de acesso à educação, algo que gradualmente se equiparou, minha atenção se dirige à separação de conteúdos e às expectativas de futuro para ambos. Visando cum- prir o objetivo do presente artigo, me atenho a problematizar as representações que cercavam e justificavam o ensino da economia doméstica, campo de conhecimentos teórico-práticos considerado ideal para as mulheres brasileiras até o terceiro quartel do século XX, em virtude de sua íntima relação com temas que diziam respeito à esfera "reprodutiva", como higiene, saúde e alimentação da família e das/os filhas/os.

Regulamentado pelo então Ministério de Agricultura, Indústria e Comércio do Brasil, no ano de 1909 eram oferecidos cursos de economia doméstica às jovens no ensino técnico-profissional. A partir do Plano $\mathrm{Na}$ cional de Educação de 1937, aprovado durante a gestão de Gustavo Capanema, Ministro da Educação e Saúde entre os anos de 1934 e 1945, foi proposta a existência de um ensino doméstico reservado a meninas de 12 a 18 anos. Tratava-se de um ensino "feminino" que tinha como objetivo preparar a mulher para atuação doméstica e formar professoras através da Escola Normal (OLIVEIRA, 2006). Com a promulgação da Lei Orgânica do Ensino Secundário de 1942, o ensino de economia doméstica foi incluído em todas as séries dos cursos ginasial, clássico e científico. Os pressupostos que estavam em questão parecem nítidos no discurso de Gustavo Capanema em uma conferência proferida dia 02 de dezembro de 1937:

Os poderes públicos devem ter em mira que a educação, tendo por finalidade preparar o individuo para a vida moral, política e econômica da nação, precisa considerar diversamente o homem e a mulher. Cumpre reconhecer que no mundo moderno um e outro são chamados à mesma quantidade de esforço pela obra comum, pois a mulher mostrou-se capaz de tarefas as mais difíceis e penosas outrora retiradas de sua participa- 
ção. A educação a ser dada aos dois há, porém, de diferir na medida em que diferem os destinos que a Providência lhes deu. Assim, se o homem deve ser preparado com têmpera de teor militar para os negócios e as lutas, a educação feminina terá outra finalidade que é o preparo para a vida do lar. A família constituída pelo casamento indissolúvel é a base de nossa organização social e por isto colocada sob a proteção especial do Estado. Ora, é a mulher que funda e conserva a família, como é também por suas mãos que a familia se destrói. Ao Estado, pois, compete, na educação que lhe ministra prepará-la conscientemente para esta grave missão (CAPANEMA, 1937 ${ }^{4}$, apud SCHWARTZMAN ET AL. 2000, grifo nosso).

Para o Estado Novo seria preciso considerar de forma diferente o homem e a mulher. A educação que ambos receberiam deveria fazer jus aos destinos que a providência lhes deu: o homem ocupado de questões militares e produtivas, e a mulher voltada à vida do lar. A família, tida como a base da organização social, era colocada sob proteção do Estado, e tendo em vista que é a mulher que deveria conservar a família (física e moralmente), ela precisaria ser educada para o devido cumprimento de sua missão. $\mathrm{Na}$ interpretação de Maria de Fátima Lopes (2012, p. 3), ao longo do século XX se fortaleceu esse campo disciplinar que, considerando suas origens, se definia como uma "ciência de e para mulheres",

[...] que permanece feminino em toda sua trajetória. Trata-se de um campo que se constrói para ser estudado por mulheres, dando tratamento cientifico aos conhecimentos empíricos de donas-de-casa, que se divide em áreas de conhecimentos para dar conta do universo doméstico.

Fruto de um convênio firmado com a Universidade de Purdue, dos Estados Unidos da América, o primeiro curso de graduação em Economia Doméstica no Brasil surgiu no ano de 1952, quando implantada a Escola Superior de Ciências Domésticas (ESCD) da Universidade Rural do Estado de Minas Gerais (UREMG), atualmente Universidade Federal de Viçosa (UFV) (UFV, 2017). Na análise de Lopes (2012, p. 6-7), a implementação da ESCD seria um exemplo de como a "institucionalização do conhecimento" reflete não apenas um “desejo pessoal de um indivíduo" ou de um coletivo específico, mas sim a "conjugação de esforços que conciliem interesses políticos, acadêmicos e institucionais". Com iniciativas desse tipo, o objetivo era disseminar determinados valores e hábitos através do sistema educacional.

A gradual expansão de aparatos institucionais e recursos orientados para promover conhecimentos em economia doméstica no Brasil ilustra bem o caráter produtivo do poder, como apontou Michel Foucault, haja vista ter gerado novos discursos, novos tipos de conhecimento (economia doméstica, puericultura, nutrição, etc.), novos objetos de conhecimento (a mulher e o trabalho doméstico), novas práticas (metodologias e formas de fazer em assuntos como administração do lar, saúde e alimentação) e insti-

4. Gustavo Capanema. Conferência proferida por ocasião do centenário do Colégio Pedro II, 2 de dezembro de 1937. GC/Capanema, Gustavo, 02.12.37, série pi. 
tuições/pastas (departamentos das universidades que passariam a lecionar esses temas, como a UREMG, departamentos de economia doméstica em associações de assistência técnica e extensão rural e em órgãos como o Serviço Social Rural, entre outros). Havia um universo por trás da ligação entre a mulher e o âmbito doméstico, o que compreendia tipos de objetos de conhecimento, metodologias, instituições, juízos e, não menos importante, representações.

Nesse interim, as discussões travadas no Encontro de Economia Doméstica, realizado em 1961 na cidade do Rio de Janeiro (BRASIL, 1961), dão mostras do que estava em debate para a educação da mulher à época, servindo de exemplo para compreender os modos como as práticas representacionais de estereotipagem operam na produção da diferença de gênero. Instituições e agentes dedicadas/os à educação escolar e extraescolar de mulheres com base nesse campo de conhecimento, frequentaram o evento, como a Campanha de Aperfeiçoamento e Difusão do Ensino Secundário (CADES), a Universidade Rural do Estado de Minas Gerais (UREMG), o Serviço de Informação Agrícola (SIA), o Serviço Social Rural (SSR), Associação Brasileira de Crédito e Assistência Rural (ABCAR), Associação Sulina de Crédito e Assistência Rural (ASCAR), entre outras. Meu interesse por analisar as apresentações desse evento está associado à possibilidade de compreender parte do imaginário construído pelas entidades que promoviam os conhecimentos de economia doméstica, à época, a respeito de seu objeto de intervenção: a mulher e o lar, e especialmente o papel que elas deveriam cumprir junto à família e à sociedade na cruzada pelo desenvolvimento nacional.

$\mathrm{Na}$ interpretação de Zail Gama Lima, professora de economia doméstica da Cam- panha de Aperfeiçoamento e Difusão do Ensino Secundário (CADES), haveria a necessidade de

[...] preparar nossas jovens para se desincumbirem das funções que lhes competem na sociedade, como futuras mães, esposas, como donas de casa, como cidadãs, e, essencialmente, como responsáveis pela preservação dos princípios morais e cristãos da familia e, consequentemente, da comunidade, e o desejo de proporcionar às jovens os meios de adquirirem hábitos de trabalho ativo e criador dentro dos princípios de uma educação completa: moral, cultural, artística e prática, capaz de conduzi-las à sua formação integral (BRASIL, 1961, p. 65, grifo nosso).

Segundo Zail, a "finalidade" das educadoras em economia doméstica seria "despertar o interesse e orientar a reflexão das jovens alunas para os problemas de direção da família”, o que passava por procurar "na alma dessas adolescentes o amor pelo lar, o interesse pela criação de uma vida doméstica mais confortável, mais tranquila e mais feliz" (BRASIL, 1961, p. 65-66). Além do uso de intensificações (mais, mais...), para essa educadora, o possível amor pelo lar já estaria na alma das jovens, parte de uma essência feminina, faltando apenas ser despertado pelas educadoras. A domesticidade e a responsabilidade por valores morais e religiosos eram interpretadas como um valor feminino, cabendo às professoras buscar no "âmago das almas e procurar o entusiasmo" e o "encanto das alunas por um lar higiênico e alegre, embora pobre", despertando sua "natural destinação para a vida do lar" (BRASIL, 1961, p. 69).

Repetindo a crença de uma estreita relação entre a mulher e o futuro da sociedade, 
na argumentação de Zail Gama Lima seria necessário "formar boas donas de casa" que "promovam lares felizes para garantir a estabilidade da família, célula da própria sociedade" (BRASIL, 1961, p. 66). Entretanto, à época, não se discutia qualquer tipo de família. A família nuclear modelo do mundo ocidental, sustentada por uma divisão do trabalho onde o homem aparece como "chefe da família" e a mulher como "esposa, mãe e dona-de-casa”, era tomada como o "padrão":

Na família-padrão a atividade feminina ficaria restrita ao ambiente da casa, isto é, a mulher não deverá exercer profissão remunerada fora do lar. 0 orçamento em que apareça proventos resultante do trabalho da dona de casa não será o orçamento da família-padrão. No orçamento desta última a receita será representada pelo resultado da atividade do homem [...] (SERRANO, 1958, p. 148).

Retirada do livro Noções de Economia Doméstica, a percepção de Isabel de Almeida Serrano (1958) parece clara na defesa de um padrão de entendimento que naturalizava a apropriação econômica por parte do homem. Quando usa a expressão "família-padrão”, a autora faz menção a um número de cinco pessoas, pai, mãe e três filhos, incluindo a "perfeita saúde de seus membros, estabilidade econômica" e a "boa formação moral e cultural” (SERRANO, 1958, p. 147). No centro desse tipo de percepção, é justamente da posição que a mulher ocuparia dentro lar que afloravam argumentos sobre sua responsabilidade e missão com a família e a sociedade, pois como sugere o raciocínio da apresentação de Maria José Felicísimo Campos, Educadora Familiar do Serviço Social Rural (SSR), no Encontro de Economia Doméstica, o "valor" da mulher passaria justamente pela sua capacidade de, como mãe/esposa, transmitir conhecimentos para os membros da família:

Como mãe de família ela é realmente educadora, que transmite a todo instante conhecimentos aos que em torno dela vivem e crescem. A mulher é, incontestavelmente, o baluarte da família, quer como educadora ou administradora do lar. E a família, por sua vez, é o alicerce da sociedade (BRASIL, 1961, p. 49).

Se a busca pelo bem-estar social da nação compunha o discurso oficial do Estado, o que tornava "necessária” uma "mudança social dirigida e orientada" da comunidade na visão de Maria José, seria um erro "prescindir da valiosa colaboração da mulher" (BRASIL, 1961, p. 48). Com um argumento semelhante, ao abordar temas como os valores da população, da família e da mulher rural, o técnico da Superintendência do Ensino Agrícola e Veterinário de MG (SEAV-MG), Roberval Cardoso, enaltece o papel que a mulher cumpriria no âmago da família: "não somente ao homem, mas quiçá, muito mais devemos à mulher rural”, a fiel "companheira do homem no meio rural" (BRASIL, 1961, p. 14). Para ele, além de sua atuação ao irradiar conhecimentos para os membros da família, sua importância passava por um conjunto de características inerentes à sua natureza feminina:

Possuindo ela um temperamento mais propenso à fantasia e ao sonho, retém os contos, as lendas e os cânticos populares, transmitindo às novas gerações a 'alma da pátria', desde o ninar das crianças; mais jeitosa para os trabalhos de arte aplicada (pano e agulha, pintura, cerâmica e etc.), é a maior obreira da arte popular, o professor máximo do artesanato doméstico, desde a misteriosa vovó-índia, da cerâmica marajoara. [...] A própria re- 
ligião, nesses locais onde por anos seguidos não aparece um sacerdote, teria desaparecido e a família retornado à animalidade se não fora a mulher rural ensinando aos filhos o Padre Nosso e o Sinal da Cruz, transmitindo os cânticos religiosos, contando a vida dos santos [...] (BRASIL, 1961, p. 15-16).

Atribuindo à mulher rural características como maior sensibilidade, acesso à fantasia e ao sonho, e o fardo de mantenedora e transmissora de lendas fundamentais para a permanência do modo de vida e do imaginário popular, sendo representada como portadora de tradições ligadas ao passado histórico e mítico da nação (UNGER, 2010), é interessante ver como a mulher também é concebida como guardiã da moral cristã e da civilidade da família, da comunidade e, por conseguinte, da sociedade. Na interpretação de Roberval Cardoso, a mulher seria responsável por evitar que o homem, quando afastado de representantes e dos valores cristãos, voltasse à animalidade. A mulher era associada à civilidade e a valores religiosos, nos revelando as expectativas de um papel regenerador (LOURO, 2011). Semelhante à posição de Roberval, Ecilda Cesconetto, à época encarregada pelo Setor de Economia Doméstica do Serviço de Informação Agrícola (SIA), vai mais adiante sobre as obrigações da mulher com a sociedade em sua apresentação "a mulher em direção ao lar":

[...] desde as mais remotas eras, vem a mulher ocupando o lugar que lhe foi destinado pelo criador, como elemento humano essencial para a grandeza e sobrevivência dos povos e das civilizações. [...] Exercendo funções idênticas às do homem, nas artes, nas ciências e nas profissões liberais, a mulher foi aos poucos afastando-se do aconchego do lar, solicitada pelas novas condições sociais e nelas atuando, já agora, como elemento indispensável, do que resultaram reflexos nem sempre positivos para a familia, e, consequentemente, para a própria sociedade. [...] E por isso talvez, em nossos dias, grande soma de agravamento dos problemas sociais tenham sua causa remota na condição da mulher, em parte desajustada, com a dissolução dos lares, a desagregação de seus membros, o abandono da juventude e outros males que todos conhecemos. [...] Na família, a mulher deve ser o centro de irradiação e o ponto para o qual convergem todos os problemas relacionados com o lar. Assistência permanente, educação religiosa, moral e cívica, o amor e respeito mútuo e o bem-estar da família são reflexos da presença e atuação da mulher dentro do lar. [...] E à mulher cabe manter todos esses valores, guarda-los e conservá-los, através de uma atuação segura e capaz, permanente e profunda, dentro de seu pequeno mundo (BRASIL, 1961, p. 20-21, grifo nosso).

A posição de Ecilda Cesconetto nos remete à fala de Gustavo Capanema em 1937, pois se a mulher funda e conserva a família, é também por suas mãos que ela pode se destruir. Segundo Ecilda, em virtude de seu gradual afastamento do âmbito doméstico recairia sobre a mulher uma parcela remota da responsabilidade por fenômenos sociais como a desestruturação familiar e seus efeitos, um desajuste frente às representações e ao papel ideal até então prescrito. Para ela, a mulher seria o "centro de irradiação" e o ponto para o qual os problemas do lar deveriam convergir, e por isso mesmo seria imperativo que permanecesse dentro de seu pequeno mundo, mantendo e reproduzindo valores religiosos, cívicos e familiares. A restrição de 
Ecilda Cesconetto é cruel: deveria a mulher se preocupar com temas dessa monta apenas restrita a seu pequeno mundo. Mas como poderia caber dentro desse pequeno mundo a quantidade de papéis e responsabilidades atribuída?

Para Ana Carla Menezes de Oliveira (2006), por ser um período de intensas mudanças sociais, o número de separações disparou na metade do século XX. Nesse momento, talvez "a maior preocupação da sociedade" fosse "que o lar e as famílias estavam deteriorando-se" (OLIVEIRA, 2006, p. 79). A instituição familiar, até então encarada como uma "provedora do cuidado, criação e formação necessários ao bem-estar das pessoas na sociedade”, estaria ameaçada, ganhando força a crença de que, caso "falissem, a sociedade poderia também falir”, uma vez que os "lares e famílias foram, não muito distante", provedores de "habilidades e influências éticas” (OLIVEIRA, 2006, p. 79). Na concepção dos participantes do Encontro de Economia Doméstica e de educadoras como Isabel de Almeida Serrano, reverter esse dilema passava por desenvolver na mulher um espirito de previdência e economia, ensinar sobre a aquisição, utilização, conservação e transformação de utensílios domésticos, propor mudanças em hábitos alimentares e aproveitamento de alimentos, ensinar sobre puericultura às futuras mães, divulgar saberes para prevenção contra acidentes e noções básicas de enfermagem, e, não menos fundamental, "transformar uma casa habitada por uma família em um lar”, o que, segundo Zail Gama Lima, significava desenvolver determinadas “condições higiênicas, materiais e morais” (BRASIL, 1961 p. 66-67).

As funções morais da mulher aparecem com significativa frequência no livro $\mathrm{No}$ - ções de Economia Doméstica de Isabel de Almeida Serrano (1958) e são tidas como o elo de estabilidade entre família, sociedade, nação e civilidade, ligação também recorrente na maioria dos painéis do Encontro de Economia Doméstica:

É sobre os joelhos maternos que se forma o que de maior e mais útil há no mundo: um homem de bem. [...] seria impossivel conceber-se a ideia de pátria sem se admitir a família, o primeiro grupo social - 'o mais essencial de todos os elementos que compõe as grandes aglomerações de homens chamadas nações'. [...] sem a família o homem seria apenas um selvagem. Primeiro oásis da civilização no deserto da barbárie, a familia é o asilo bendito (SERRANO, 1958, p. 20-21, grifo nosso).

[0 homem] [...] como um general, traça os planos e deixa a execução à esposa. Esta, com o espirito de análise peculiar à mulher, com o trato e a delicadeza que lhe são características, tem o seu largo a formação básica do caráter infantil, moldando-o, corrigindo lhe os defeitos, depositando naquela terra virgem as sementes virtudes que mais tarde formarão o homem justo e o bom cidadão. [...] Pode-se afirmar, sem exagero, que as mãos femininas constroem, num silencioso e obscuro trabalho de formiga, o grandioso monumento da civilização. [...] é a mulher o anjo tutelar da família [...] (SERRANO, 1958, p. 20-21, grifo nosso).

0 conhecimento de economia doméstica é imprescindivel às donas de casa. Sem ele, a mulher não poderá cumprir os seus deveres de mãe de família e causará grandes males a si própria, aos seus e à sociedade (SERRANO, 1958, p. 23). 
Esposa, mãe e mestra, forma o cidadão e imprime-lhe a marca do homem justo e bom. Ela, na verdade, é quem prepara a sociedade futura, embalando o filhinho ou ensinando o discípulo (SERRANO, 1958, p. 231, grifo nosso).

[...] a família é a célula da sociedade. Quanto melhor organizado for o grupo familiar, tanto mais perfeito será o agregado social. Como a organização familiar depende precipuamente da ação feminina, isto é, da atuação da dona de casa, a influência da mulher, como esposa e gerente do lar, assume capital importância para o bem da sociedade em geral. [...] Corrigindo as asperezas do caráter masculino, suavizando sofrimentos, enxugando lágrimas, despertando a esperança, dando fé e coragem aos momentos de desânimo de angústia, será na verdade a mulher a construtora de um mundo melhor (SERRANO, 1958, p. 236, grifo nosso).

A mulher era tida como a responsável por um mundo melhor, seja porque manteria a família saudável e firme em seus valores morais, cívicos e religiosos, seja porque prepararia o homem e a mulher do futuro. Como o francês Jacques Donzelot sugere no interessante livro A polícia das familias (1980, p. 67), se estava em jogo moralizar o comportamento para restaurar a vida familiar, seria justamente "através da mulher, através do ensino que a elas se proporciona, que as normas de uma vida sã, regular e disciplinada" poderiam "ser introduzidas na vida doméstica”. No contexto social e político do Brasil da metade do século XX, os conhecimentos em economia doméstica surgiam como alternativa para que houvesse o cumprimento tido como adequado dos deveres da mulher com a família e a sociedade, e, para isso, sua maior justificativa era o caráter "científico" desse campo. Essa percepção era tributária do sentimento modernizante que, à época, pairava sobre instituições educativas e de promoção do desenvolvimento. Na interpretação de Maria das Dores Carvalho Ferreira, então Diretora da Escola Superior de Ciências Domésticas da Universidade Rural do Estado de Minas Gerais (UREMG), seriam justamente os hábitos ultrapassados que a mulher manteria na realização das tarefas domésticas, que teriam intensificado o afastamento da mulher de seu santuário, o lar, se fazendo necessário a transmissão de conhecimentos e atitudes mais sintonizadas com os novos tempos:

[Haveria a] [...] necessidade de pôr o lar ao nível das demais atividades humanas, neste século que chamou de luzes e que se poderia denominar também das bombas. Tudo se procura, hoje, processar com a aplicação das leis científicas decorrentes da observação e da interpretação dos fenômenos da vida. Por que segurar as atividades domésticas e mantê-las, retrogradamente, à luz de princípios rotineiros de séculos passados? [...] Tanto mais se faz necessária adoção de atitude nova, quanto mais se efetua a emancipação da mulher, iniciada no século passado e, em algumas regiões do globo, ultrapassada, aliás, para desastre de $f a-$ milia. É que o trabalho doméstico, se permanecer nos hábitos de nossos maiores, afastará cada vez mais a esposa do seu santuário, o lar. Este deverá dar a ela um campo de atitudes vasto, atual, atraente, absorvente, digno, nobre, elevado, sintonizado com os tempos, no que eles têm de melhor [...], [com os] olhos postos no futuro do nosso Estado [...] e Pátria (BRASIL, 1961, p. 60-61, grifo nosso).

A resposta para esse diagnóstico problemático de saída da mulher do âmbito doméstico seriam os conhecimentos em eco- 
nomia doméstica, em tese capazes de proporcionar uma "solução adequada e eficiente" aos problemas do lar e seu suposto desajuste (SERRANO, 1958, p. 25). Na interpretação de Roberval Cardoso, ter-se-ia na mulher o "elemento fundamental" para "racionalização da vida e do lar [...], necessitando, porém, para que suas qualidades" pudessem obter "um máximo de rendimento, receber cuidadosa preparação" (BRASIL, 1961, p. 16). Como analisa Guacira Lopes Louro (2011), com base em ideais positivistas e cientificistas buscava-se justificar um ensino para mulher que, imbricado à função materna, afastaria as superstições e favoreceria as romantizadas novidades da ciência. A introdução de novas áreas científicas para o trabalho no lar, como puericultura, economia doméstica e outras, portanto, era justifıcada por velhas concepções relativas à essência do que, à época, se entendia como feminino (LOURO, 2011). Não obstante os progressos e conquistas do período, esse tipo de permanência é comentado por Susan Moller Okin (2008, p. 312-313, grifo nosso):

A maioria das feministas do século XIX - e do início do XX - não questionou ou desafiou o papel especial da mulher no interior da familia. Na verdade, elas frequentemente defenderam os direitos e oportunidades das mulheres, como a educação ou o sufrágio, com o argumento de que fariam dessas mulheres esposas e mães melhores, ou que as capacitariam para trazer sua sensibilidade moral especial, desenvolvida na esfera doméstica, para o mundo da política. Assim, ainda que elas lutassem contra a subordinação jurídica das esposas e exigissem direitos iguais para as mulheres na esfera pública, elas aceitaram a suposição prévia de que a associação estreita com a esfera doméstica e a responsabilidade da mulher por essa mesma esfera eram naturais e inevitáveis.

Os discursos citados e outros semelhantes da segunda metade do século XX sugerem que o espaço do lar, tido como naturalmente feminino, "não continuava sendo o lugar onde ela naturalmente adquiria os saberes considerados necessários para sua ação", o que era justificado pela saída da mulher para o mercado de trabalho e seu "possível despreparo para as tradicionais tarefas de dona de casa”, bem como pela "administração e o cuidado do lar" terem se transformado em um desafio diferente "na moderna sociedade: novas máquinas e tecnologias haviam sido introduzidas; ser mãe era uma tarefa também diferente" (LOURO e MEYER, 1993, p. 49). Nascia aí uma disputa quanto à legitimidade de conhecimentos e hábitos ligados ao doméstico, uma vez que ao estabelecer a profissão de "especialistas" como "valiosa”, foi necessário duvidar da "qualidade da tradicional competência” das donas de casa (LOURO e MEYER, 1993, p. 50). A importância atribuída a essa qualificação é ilustrada na visão de Serrano (1958, p. 13, grifo nosso):

Cada profissão possui a sua técnica especializada. Por que somente a mãe de família, a dona de casa, não se especializará na técnica e na ciência de uma das mais elevadas e complexas funções sociais, qual a de formar e dirigir seu lar, ser mãe e ser esposa, estruturando o caráter dos homens e das mulheres que irão constituir a sociedade de amanhã?

Como Serrano (1958, p. 15) sugere em seção chamada de Explicações necessárias, "desde a infância" as "pertencentes ao sexo feminino" manifestariam "acentuada tendência para os misteres domésticos”, es- 
tes "misteres sublimes para os quais nascemos”. Ela então se pergunta: "por que não desenvolvemos as nossas tendências, orientando-as à proporção que vamos crescendo?”. Essas e outras naturalizações, reduções e essencializações apresentadas nesse escrito dão mostras de como operam as práticas representacionais de estereotipagem estudadas por Stuart Hall (2016). Articuladas e difundidas através do quadro técnico de instituições educativas e de promoção do desenvolvimento, esse tipo de representação servia à manutenção e à resignação da mulher para com uma função social de esteio da saúde e da moral das famílias e da sociedade, perpetuando certas imagens e predestinações. No entanto, ainda que a mulher brasileira tenha precisado (e siga precisando) enfrentar limitações e diferenciações motivadas por gênero, é preciso reconhecer que os sujeitos concretos não cumprem sempre, ou mesmo cumprem literalmente, os termos dessas prescrições. De certo, as mulheres brasileiras elaboraram de diferentes formas a resignação ou a resistência às imposições, muitas vezes estando em discordância às proposições sociais de seus tempos (LOURO, 2011). A conquista por direitos civis, sociais, políticos e as batalhas diárias (nem sempre estudadas) em nome de mais igualdade, representam a força dessa resistência.

\section{Considerações finais}

[...] a mulher tem sempre a mesma poesia: a de trabalhar para ser agradável, útil, boa, para satisfazer uma necessidade moral e integral do esposo e da família, revelando-se amorosa e digna do doce e pesado encargo que a sociedade lhe destinou [...] (ALMEIDA, $1905^{5}$ apud SERRANO, 1958, p. 25).
Me preocupo com a ausência da mulher de casa. Hoje, a mulher tem estado muito fora de casa. Costumo brincar como eu gostaria de estar em casa toda a tarde, numa rede, e meu marido ralando muito, muito, muito para me sustentar e me encher de joias e presentes. Esse seria o padrão ideal da sociedade. Mas, não é possível. Temos que ir para o mercado de trabalho. [...] A mulher nasceu para ser mãe [...]. [É] o papel mais especial da mulher. A gente precisa entender que a relação dela com o filho é uma relação muito especial. E a mulher tem que estar presente. A minha preocupação é: dá pra gente ter carreira, brilhar, competir, consertar as bobagens feitas pelos homens. Sem nenhuma guerra, mas a gente conserta algumas. Dá pra gente ser mãe, mulher e ainda seguir o padrão cristão que foi instituído para as nossas vidas (Damares Regina Alves citada em reportagem de João Paulo Saconi, 30 nov. 2018).

Chegou o momento de tecer algumas considerações finais a respeito das análises promovidas no presente artigo. É preciso sublinhar que, nas fontes de pesquisa consultadas, as práticas representacionais de estereotipagem operadas para a construção da diferença de gênero passaram pela naturalização da mulher como portadora de características como afeto, bondade e sensibilidade, religiosidade, moralidade e civilidade. Esses predicados serviam para justificar a crença na naturalidade de ligações da mulher com o âmbito doméstico e atividades associadas à reprodução, à vida e ao cuidado da família (em termos de saúde, higiene e alimentação), bem como, dos efeitos (negativos se contestados, ou positivos se seguidos) que isso poderia gerar na estabilidade e no bem-estar da socie- 
dade. Sua educação e formação intelectual no período considerado, por conseguinte, se alinhavam e reforçavam esse tipo de representação, mesmo que isso ganhasse ares renovados ou modernos a partir da metade do século XX. Como resultado, se pensava a educação da mulher "para além dela” (LOUR0, 2011), justificando-as não por seus próprios anseios ou curiosidades, mas pela função social que deveria cumprir dentro da família.

Mas que relações isso guarda com o Brasil do século XXI? Os ecos desse tipo de representação e das práticas educativas que se buscavam perpetuar, parecem se manifestar (e ganhar ares de contemporâneo) nas discussões públicas apresentadas na introdução e na segunda citação que abre a presente seção. A ideia de um "padrão ideal" de sociedade onde a mulher atua preferencialmente no âmbito doméstico, incluindo preocupações sobre sua ausência, e de que ser mãe representaria o "papel mais especial” da mulher e parte do "padrão cristão instituído”, dão mostras de como antigas representações seguem sendo reivindicadas como mais verdadeiras ou incontornáveis que outras. A opção pela criação do Ministério da Mulher, Família e Direitos Humanos, por exemplo, é emblemática. Associar "mulher" e "família" parece uma escolha informada e legitimada por parte do conjunto de significados e predicados analisados neste artigo. Hoje, como ao longo do século XX, segue sendo preciso investir contra representações que defendem uma versão limitada de normalidade e gênero, arraigada em um discurso conservador de defesa da moral familiar e cristã que se articula com vistas a perpetuar sua hegemonia.

Não há neutralidade nesse tipo de disputa, como advogam seus defensores, sua natureza política é cotidiana e histórica. Contra es- se culto à neutralidade, esse "olhar" que vem de lugar nenhum e que se alega enxergar sem ser visto, talvez seja mais produtivo nos arriscarmos em algo semelhante à objetividade feminista proposta por Donna Haraway (1995, p. 26), uma "prática de objetividade que privilegie a contestação, a desconstrução" e a "esperança na transformação dos sistemas de conhecimento e nas maneiras de ver". Para ela, isso passa pela produção de saberes localizados que valorizem uma perspectiva parcial e não generalista. Longe de exaltações a um eu transcendental que tudo vê e em nada interfere, o "eu dividido e contraditório é o que pode interrogar os posicionamentos e ser responsabilizado, o que pode construir e juntar-se a conversas racionais e imaginações fantásticas que mudam a história” (HARAWAY, 1995, p. 26). Considerando o que está em disputa, é imperativo seguirmos as conversas, aprender e fazer a diferença e lançar nosso destino para certos modos de vida ao invés de outros (HARAWAY, 2018). Enfim, questões que permanecem abertas.

\section{Referências}

BAHRI, D. Feminismo e/no pós-colonialismo. Revista Estudos Feministas, Florianópolis, v. 21, n. 2, p. 659-688, maio/ago., 2013.

BONILHA, J. C. A produção literária na Revista Feminina (1915-1936). In: SIMPÓSIO INTERNACIONAL DE LETRAS E LINGUÍSTICA. v. 3, n. 1. Uberlândia: EDUFU, 2013.

BRASIL. Lei no 3.071 , de $1^{\circ}$ de janeiro de 1916. Código civil dos Estados Unidos do Brasil. Presidência da República, Casa Civil, Subchefia para Assuntos Jurídicos. Rio de Janeiro-RJ, 1º jan. 1916. Disponivel em: <http://www.planalto.gov.br/ccivil_03/ leis/L3071.htm>. Acesso em: 20 dez. 2018.

. Ministério da Agricultura. Encontro de economia doméstica. Rio de Janeiro-RJ, 1961. 
BUTLER, J. Problemas de gênero: feminismo e subversão da identidade. Tradução de Renato Aguiar, Rio de Janeiro: Civilização Brasileira, 2003.

CARULA, K. A imprensa feminina no Rio de Janeiro nas décadas finais do século XIX. Estudos Feministas, Florianópolis, v. 24, n 1, p. 261-279, jan./abr., 2016.

DONZELOT, J. A polícia das famílias. Rio de Janeiro: Graal, 1980.

DUARTE, C. L. Feminismo e literatura no Brasil. Estudos avançados, v. 17, nº 49, p. 151-172, 2003. Imprensa feminina e feminista no Brasil: Século XIX. Dicionário Ilustrado. 1. ed. Belo Horizonte: Autêntica, 2016.

FANON, F. Pele negra, máscaras brancas. Tradução de Renato da Silveira. Salvador: EDUFBA, 2008.

FAUSTO-STERLING, A. Dualismos em duelo. Cadernos Pagu, Campinas, n. 17-18, p. 9-79, 200102 .

FOUCAULT, M. A arqueologia do saber. Tradução de Luiz Felipe Baeta Neves, 3. ed. Rio de Janeiro: Forense Universitária, 1987.

Resumo dos Cursos do Collège de France (1970-1982). Tradução de Andréa Daher. Rio de Janeiro: Zahar, 1997.

HALL, S. Cultura e representação. Rio de Janeiro: Editora PUC-Rio: Apicuri, 2016.

HARAWAY, D. J. Saberes localizados: a questão da ciência para o feminismo e o privilégio da perspectiva parcial. Cadernos Pagu, Campinas, n. 5, p. 7-41, 1995.

The companion species manifesto: dogs, people, and significant otherness. Chicago: Prikly Paradigm Press, 2003.

Modest-Witness@Second-Millennium. FemaleMan-Meets-OncoMouse: feminism and technoscience. Second edition. New York-NY: Routledge, 2018.
JINZENJI, M. Y. Leitura e escrita femininas no século XIX. Cadernos Pagu, Campinas, n. 38, p. 367394, jan./jun. 2012.

LOPES, M. F. A história de um campo acadêmico feminino no Brasil. In: IX CONGRESO IBEROAMERICANO DE CIENCIA, TECNOLOGÍA Y GÉNERO, 2012. Sevilla, España, 2012. Anais eletrônicos... Sevilla. Disponível em: <https://www.oei.es/ historico/congresoctg/memoria/pdf/LopesMaria. pdf>. Acesso em: 06 maio 2020.

LOUR0, G. L.; MEYER, D. A escolarização do doméstico: a construção de uma escola técnica feminina (1946-1970). Cadernos de Pesquisa, São Paulo, n. 8, p. 45-57, 1993.

. Mulheres na sala de aula. In: DEL PRIORE, M. (Org.). História das Mulheres no Brasil. 10. ed. São Paulo: Contexto, 2011, p. 371-403.

MANCILHA, V. M. Nas páginas da Revista Feminina: a imprensa como espaço de visibilidade e atuação feminina (1920-1930). In: XXVI SIMPÓSIO NACIONAL DE HISTÓRIA, 2011. São Paulo, Brasil. Anais eletrônicos... São Paulo. Disponível em: <http://www.snh2011.anpuh.org/resources/ anais/14/1312371475_ARQUIV0_VirginiaMancilha-anpuh.pdf>. Acesso em: 06 maio 2020.

MAZZARIELLO, C. C.; FERREIRA, L. B. Gênero. In: Enciclopédia de Antropologia. São Paulo: Universidade de São Paulo, Departamento de Antropologia, 2015. Disponivel em: <http://ea.fflch.usp.br/ conceito/gênero> Acesso em: 23 maio 2019.

M'CHAREK, A. Fragile differences, relational effects: Stories about the materiality of race and sex. European Journal of Women's Studies, v. 17, $\mathrm{n}^{\circ}$ 4, p. 1-16, 2010.

MUZART, Z. L. Uma espiada na imprensa das mulheres no século XIX. Revista Estudos Feministas, Florianópolis, v. 11, n. 1, p. 225-233, jan./jun. 2003.

NASCIMENTO, C. V.; OLIVEIRA, B. J. O Sexo Feminino em campanha pela emancipação da mulher. Cadernos Pagu, Campinas, n. 29, p. 429-457, 2007. 
NICHOLSON, L. Interpretando o gênero. Revista Estudos Feministas, Florianópolis, v. 8, n. 2, p. 9-41, 2000.

OLIVEIRA, A. C. M. Economia doméstica: origem, desenvolvimento e campo de atuação profissional. Revista VÉRTICES, v. 8, n. 1/3, p. 77-88, jan,/dez., 2006.

PINHEIRO, C. F. Estado, extensão rural e economia doméstica no Brasil (1948-1974). 2016. $173 \mathrm{f}$. Dissertação (Mestrado em História) - Universidade Federal Fluminense, Niterói, 2016.

REVISTA FEMININA. Edição 32, São Paulo, 1917a, 44 p.

. Edição 34, São Paulo, 1917b, 60 p.

Edição 35, São Paulo, 1917c, 56 p.

Edição 39, São Paulo, 1917d, 56 p.

Edição 42, São Paulo, 1917e, 44 p.

SACONI, J. P. Cotada para ministra diz que 'mulher nasce para ser mãe' e 'infelizmente tem que ir para o mercado de trabalho'. Jornal “O Globo", Rio de Janeiro, 30 nov. 2018. Disponível em: <https://oglobo.globo.com/brasil/cotada-para-ministra-diz-que-mulher-nasce-para-ser-mae-infelizmente-tem-que-ir-para-mercado-de-trabalho-23272762>. Acesso em: 29 maio 2019.

SAID, E. W. Orientalismo: o Oriente como invenção do Ocidente. São Paulo: Companhia das Letras, 2007a.

- Humanismo e crítica democrática. São Paulo: Companhia das Letras, 2007b.

SALVADOR, T. Em torno dos periódicos femininos. Cultura: Revista de História e Teoria das Ideias, v. 26, p. 95-117, 2009.

SCHWARTZMAN, S.; BOMENY, H. M. B.; COSTA, V. M. R. Tempos de Capanema. 2. ed., Rio de Janeiro: Fundação Getúlio Vargas e Editora Paz e Terra, 2000, n.p.

SCOTT, J. W. Gênero: uma categoria útil de análise histórica. Educação \&t Realidade. Porto Alegre, vol. 20, n. 2, p. 71-99, jul./dez. 1995.
. Género e historia. Traducción de Consol Vilà I. Boadas. México: Universidad Autónoma de la Ciudad de México, 2008.

SERRANO, I. A. Noções de economia doméstica. 9. ed. São Paulo: Companhia Editora Nacional, 1958.

STRATHERN, M. Necessidade de pais, necessidade de mães. Revista Estudos Feministas, v. 3, n. 2, Florianópolis, p. 303-329, 1995.

UNGER, C. Histories of Development and Modernization: Findings, Reflections, Future Research. H-Soz-Kult. Disponível em: <http://hsozkult.geschichte.hu-berlin.de/forum/2010-12-001>. Acesso em: 20 dez. 2018.

UNIVERSIDADE FEDERAL DE VIÇOSA. Departamento de Economia Doméstica. Site institucional (histórico). Disponivel em: <http://www.ded.ufv. br/?page_id=626>. Acesso em: $20 \mathrm{dez} .2018$. 


\section{RESUMO}

Este artigo consiste no estudo da natureza política subjacente à produção da diferença de gênero. Partindo de dilemas políticos do Brasil do século XXI, o objetivo é explorar como significados e predicados que suscitam o feminino foram invocados para produzir diferenças e prescrever ou contestar certas representações em vez de outras ao longo do século XX. Para tal, me apoio em três fontes de pesquisa: o periódico Revista Feminina (1917); o livro Noções de economia doméstica, de Isabel Serrano (1958); e os painéis do Encontro de Economia Doméstica (1961). 0 material é analisado a luz de conceitos e problemas de diferentes origens disciplinares e inspirações teóricas interessadas no estudo de marcadores sociais da diferença. As análises sugerem que a produção da diferença é tributária de práticas representacionais e educativas que naturalizam e tentam perpetuar valores e predestinações que associam a mulher ao lar e ao bem-estar da família e sociedade.

\section{PALAVRAS-CHAVE}

Produção da diferença de gênero. Educação. Século XX.

\section{ABSTRACT}

This article consists of the study of the political nature underlying the production of gender difference. Starting from political dilemmas of 21st century Brazil, the objective is to explore how meanings and predicates that arouse the feminine were invoked to produce differences and prescribe or challenge certain representations rather than others throughout the 20th Century. For that, I rely on three sources of research: the journal Revista Feminina (1917); the book Noções de Economia Doméstica, by Isabel Serrano (1958); and the panels of the Encontro de Economia Doméstica (1961). The material is analyzed in light of concepts and problems of different disciplinary origins and theoretical inspirations interested in the study of social markers of difference. The analyses suggest that the production of difference is tributary of representational and educational practices that naturalize and try to perpetuate values and predestinations that associate women to the home and to the well-being of family and society.

\section{KEYWORDS}

Production of gender difference. Education. 20th Century. 